\title{
AGRICULTURAL POLICY REFORMS AND THEIR IMPLICATIONS ON RURAL DEVELOPMENT: TURKEY AND THE EU
}

Melike AKKARACA KÖSE*

\section{Özet}

Son on yılda iç ve dış koşullartn etkisi ile hem AB'nde hem Türkiye'de tarım politikası alanında radikal denebilecek reformlar gerçekleştirilmiştir. AB 2009 yılından beri tarımda yeni reform önerilerini tartı̧makta iken, Türkiye'de 2009 yllinda tarım politikalarında AB'den farklı bir yöne doğru, yeni bir değişim başlamıştır. Bu çalışmada reform süreçlerinin arka planları ve kapsamları ele alındiktan sonra, yeni politikaların özellikle kırsal kalkınma ve yoksulluk açısından sonuçları eleştirel bir gözle değerlendirilmektedir. Çalışma AB'ye aday bir ülke olarak Türkiye tarımını ve tarım politikalarını Avrupa Birliği ve Birliğe Üye ülkeler ile karşılaş̧tırmalı bir biçimde tartışırken, bir yandan da AB ortak tarım politikasindaki reformların özellikle yeni üye ülkeler açısından sonuçlarını inceleyerek, Türkiye'nin tarım ve kirsal kalkınma politikaları açısından gelecekte karşılaşabileceği güçlükleri anlamayı amaçlar.

Anahtar Kelimeler: Türkiye Tarımı, Ortak Tarım Politikası, AB Genişlemesi, Kirsal Kalkinma, Kırsal Yoksulluk

\section{Abstract}

In the last ten years, the agricultural policies of both the EU and Turkey have been reformed in a radical way, due to various external and internal factors. Since 2009, the $E U$ has been discussing the new reform proposals in the CAP, while Turkey's agricultural policies have begun to evolve in a completely different direction. At this paper, the consequences of the new agricultural policies in terms of rural development and rural poverty are evaluated with a critical eye, after a brief discussion about their background, objectives and content. The paper aims to understand the difficulties that Turkey may encounter regarding its agricultural and rural policies in the future, by elaborating Turkey's agriculture and agricultural policies in comparison with the EU

* Yrd. Doç. Dr., Gediz Üniversitesi, İktisadi ve İdari Bilimler Fakültesi, Siyaset Bilimi ve Kamu Yönetimi Bölümü, İstanbul 
and the EU member states and by studying the implications of the reforms in the CAP especially for the new member states.

Key Words: Turkish Agriculture, Common Agricultural Policy, EU Enlargement, Rural Development, Rural Poverty

\section{Introduction}

Agricultural policies in Turkey underwent a significant reform process in the last decade and Turkey attempted to solve long-lasting problems in the agricultural sector. However, Turkish agricultural reform program has been modified once again in 2009, while the European Union's common agricultural policy evolved into a more liberal and less-protectionist model gradually since the 2000s. To position the current situation in Turkey at agriculture and rural development within the context of Turkey's candidacy to the European Union (EU) and to observe the evolution of the Common Agricultural Policy (the CAP) more closely with its implications over the individual member states may provide us with some useful insights about the future challenges for Turkish agriculture and rural community.

\section{A Brief Look at the Turkish Agricultural Sector in Comparison with the EU}

2011 OECD Report states that Turkey is estimated to be the world's $7^{\text {th }}$ largest agricultural producer ${ }^{1}$. Turkey has 24 million hectares of agricultural land, which represents about $20 \%$ of the EU-27 agricultural land. ${ }^{2}$ The agricultural sector represents $8.3 \%$ of the Gross Domestic Production (in 2009) $)^{3}$, very close to Bulgaria (8 \% in 2009 ) and Romania $(7 \% \text { in } 2009)^{4}$; employment in agriculture is $24 \%$ of total employment (5, 2 million people in 2010$)^{5}$ whereas the EU-27's average is only $5.5 \%$ $\left(12,2\right.$. millions in 2009); average farm size is 6 hectares $^{6}$, very close to the EU-12's ${ }^{7}$

${ }^{1}$ OECD, Evaluation of Agricultural Policy Reforms in Turkey, OECD Publishing., 2011, p.7. http://dx.doi.org/10.1787/9789264113220-en, (02 February 2012).

2 Türkiye İstatistik Kurumu (TÜIK), www.tuik.gov.tr/PreIstatistikTablo.do?istab_id=53, (19 December 2011). the total arable land under permanent crops in the EU-27 was $27 \%$ of total area (432 525000 ha), approx. 117 million hectares. Agricultural Statistics; Main Results 20082009, Eurostat Pocket Books, 2010 edition, the European Commission.

${ }^{3}$ Republic of Turkey Prime Ministry, Investment Support and Promotion Agency of Turkey, Turkish Agriculture Industry Report, July 2010, p.3. It is a decline from 20\% in 1980. But this is only a proportional decline: agricultural GDP increases since 2000 and reached to USD 51 Billion in 2010.

${ }^{4}$ Situation and Prospects for EU Agriculture and Rural Areas, European Commission Directorate-General for Agriculture and Rural Development, December 2010. However, it is higher than many other EU member-states such as 4\% in Hungary, 3,5\% in Poland, 2\% in the Czech Republic, $2 \%$ in France and Italy, $1 \%$ in Belgium and in Germany. World Bank, World Development Indicators, 2010. <http://data.worldbank.org/indicator >, (20 December 2011).

${ }^{5}$ Turkish Agriculture Industry Report, op.cit., p.3. It ranges from 1\% in the United Kingdom to around $28 \%$ in Romania, $20 \%$ in Bulgaria and $13 \%$ in Poland.

${ }^{6} 65 \%$ of agricultural holdings in Turkey have less than 5 ha. Only $5.8 \%$ of agricultural holdings have more than 20 ha. of land, but occupy $34.2 \%$ of the agricultural area. Rural Development Policies: A Chance for Turkey during the EU Accession Process?, The Heinrich Böll Foundation, 2007, pp.4-5, www.boell.be/download_en/Text_Tuerkei.pdf, (11 October 2009) 
average (6.0 ha) but less than half of the EU-27's average (14 ha in 2010$)^{8}$; rural population is $24 \%$ of the total population (2009), whereas it is $19 \%$ in the EU-27 (96.9 million people in 2009). ${ }^{9}$

Table 1. Share of Agricultural Sector in Gross Domestic Production

\begin{tabular}{|l|c|}
\hline Turkey & $\% 8,3$ \\
\hline Bulgaria & $\% 8$ \\
\hline Romania & $\% 7$ \\
\hline Hungary & $\% 4$ \\
\hline Poland & $\% 3.5$ \\
\hline France & $\% 2$ \\
\hline Belgium & $\% 1$ \\
\hline
\end{tabular}

Source: World Bank, World Development Indicators, 2012

Table 2. Avarage Farm Size

\begin{tabular}{|l|c|}
\hline Turkey & $6 \mathrm{ha}$ \\
\hline EU-12 (New Member States) & $6 \mathrm{ha}$ \\
\hline EU-27 & $14 \mathrm{ha}$ \\
\hline Czech Republic & $152 \mathrm{ha}$ \\
\hline United Kingdom & $79 \mathrm{ha}$ \\
\hline France & $53 \mathrm{ha}$ \\
\hline Greece & $6 \mathrm{ha}$ \\
\hline Slovenia & $6 \mathrm{ha}$ \\
\hline Cyprus & $3 \mathrm{ha}$ \\
\hline Romania & $3 \mathrm{ha}$ \\
\hline Malta & $1 \mathrm{ha}$ \\
\hline
\end{tabular}

Source: 2010 Agricultural Census Provisional Results

${ }^{7}$ EU-12 in the Commission documents covers the new member states of the EU since 2004.

${ }^{8}$ Situation and Prospects for EU Agriculture and Rural Areas, op.cit., p. 20. With the restructuring of the sector, the average physical size of the farm has been increasing since 1995. It increased from 12,6 ha in 2007 to 14 ha for EU-27 in 2010. The average of the EU-12 is much lower than EU-27, due to the high share of small farms in most EU-12 Member States. In the 10 new member states, average farm size is 8,6 (2007). For detailed information about the farm structure of the EU, see Agricultural Economic Briefs, Structural development in EU agriculture, Brief $\mathrm{N}^{\circ}$ 3-September 2011, European Commission: Agriculture and Rural Development, http://ec.europa.eu/agriculture/agrista/economic-briefs/, (19 November 2011). According to provisional results of Agricultural census 2010, the Czech Republic (152 ha), the United Kingdom (79 ha), Denmark (65 ha), Luxembourg (59 ha), Germany (56 ha), France (53 ha), Cyprus and Romania (both $3 \mathrm{ha}$ ), Greece and Slovenia (both $6 \mathrm{ha}$ ) and the smallest in Malta (1 ha). Eurostat news release, Reference: STAT/11/147 Date: 11/10/2011. http://ec.europa.eu/eurostat, (19 December 2011).

${ }^{9}$ Again, there are significant disparities between the Member States. At one extreme, $73 \%$ of the Irish population lived in predominantly rural regions, at the other it is only $1 \%$ of the Dutch population. In ten member states, it is more than $40 \%$ of total national population (in Ireland, Slovenia, Finland, Sweden, Poland, Austria, the Czech Republic, Hungary, Romania, and Latvia). Agriculture and Fishery Statistics, Main Results: 2009-2010, Eurostat Pocketbooks, European Commission, 2011ed. http://ec.europa.eu/eurostat, (17 November 2011). 
Turkey is a major producer of cereals (wheat, barley and maize); other crops (sugar beet, cotton, potatoes and tobacco); fruit and vegetables (especially apples, citrus, grapes, figs, hazelnuts, olives and tea); and sheep and goat meat. Turkey's agricultural exports are not highly diversified; fruits, nuts and vegetables are the major export categories (approximately $60 \%$ of total agricultural exports). Tobacco, cereals and sugar comprise a further $20 \%$. Despite the overall trade deficit of Turkey, the agricultural trade balance is significantly positive, providing some relief to external accounts. ${ }^{10}$ EU-27 member states are the destination for about 46 percent of Turkey's agricultural exports. In contrast to merchandise trade, Turkey has a trade surplus with the EU in the field of agriculture (1322 million Euros in 2010) ${ }^{11}$. The EU accounts for almost half of Turkey's agricultural exports. The EU's market share of Turkey's agricultural imports is also important, accounting for just over of $17 \%$ of total Turkish agricultural imports.

On the other hand, agriculture in Turkey has had persistent problems which led the country to undergo a radical reform process in the early years of the second millennium. There are major structural problems which include small size of agricultural holdings, fragmented and scattered farms, low efficiency, insufficiencies regarding production and marketing infrastructures. This list may be lengthened to include rural development problems: low levels of professional agricultural activity, low investment capacity, low level of education and relatively high levels of illiteracy, a large proportion of the agricultural workforce working as unpaid family labor, low income levels and lack of alternative income sources, and significant rural out-migration. The EU Commission adds to this list: ineffective institutional structures and farmer organizations, scattered settlement patterns in some regions, insufficient development of physical, social and

\footnotetext{
${ }^{10}$ There are conflicting statistical data and analysis about the trade balance, which is a point of criticism for the European Commission as well at the Screening Report of Agriculture and Rural Development ('The quality, quantity and completeness of available reliable and comparable official statistics are very limited in many sectors of the chapter Agriculture and Rural Development. This makes a detailed assessment of the current situation in the agriculture sector and comparison with EU policies and structures difficult.) According to the statistical statements of Agricultural Ministry

(http://www.tarim.gov.tr/Duyurular,haber_Detayli_Gosterim.html?NewsID=576), foreign trade in agriculture gave deficit in 2007 and 2008, but not in 2009 (data covering raw materials and agrifood.). However, according to prime ministry investment agency report (see supra note 3), Turkey's agricultural imports and exports for 2009, excluding processed food, amounted to USD 4.6 billion and USD 4.5 billion, respectively. On the other hand, according to OECD 2011 report (see supra note 1), Turkey typically enjoys a consistent trade surplus in agricultural products. Analysis of Statistics of Turkstat (on the basis of Agriculture and farming of animals, food products and beverages and tobacco products) supports this statement and Turkey seems to be net exporter until 2011. Only in 2011, imports exceed exports in agriculture and agri-food products.

11 European Commission: Agriculture and Rural Development, Country Profile, http://ec.europa.eu/agriculture/enlargement/countries/turkey/profile_en.pdf, (02 February 2012)
} 
cultural infrastructures, a high rate of subsistence ${ }^{12}$ farming, and a high rate of hidden unemployment. ${ }^{13}$

\section{Turkish Agricultural Policies: The Past and the Future}

Historically, Turkey's agricultural sector has been a rather closed, domestically oriented and highly protected sector. For decades, it had been supported by short-term price support policy instruments and did not contain any structural measures. Widely used support instruments were price supports and subsidies for input, product or credit. Price support was the most important part of Turkish agricultural policy. State owned economic enterprises and Agricultural Credit Cooperatives were commissioned to buy commodities such as cereals, tobacco, tea and sugar beet from farmers at prices determined by the government. From 1993 onwards, deficiency payments were used first for cotton and later on for olive oil, cotton, sunflower, etc. Markets were also protected by import tariffs. Output control over tobacco, hazelnuts, tea and sugar beet was applied in different ways. Input subsidies were provided on a temporary basis for fertilizers, seed, feed grain, agricultural chemicals, stud and insemination with the purpose of reducing the cost of inputs. Product based dairy and meet incentives were also implemented periodically. Credit subsidies, on the other hand, were available for input gathering in general and were more advantageous in comparison to market conditions. ${ }^{14}$

However, protectionist policies adopted for agriculture have been very frequently criticized by many circles and scholars. Some of the criticisms widely heard may be summarized as follows: these policies not result in a strong growth of agricultural output and Gross Value Added (GVA) in agriculture. On the contrary, 'the development of rural areas and agriculture in particular has been impeded by heavy government intervention in the sector, which was often counterproductive.' Since agricultural policies were abused by politicians seeking votes, a coherent and consistent formation of policy was lacking. The combination of high support prices and input subsidies, and their inconsistent use over time, slowed the agricultural sector down rather than stimulating it. Mismanagement of agriculture discouraged production of products in which Turkey has a comparative advantage ${ }^{15}$ squeezed out private sector marketers and subsidized inefficient production technologies. Additionally, those policies created

\footnotetext{
${ }^{12}$ Farms where the farm household consumes more than half of the farm production.

${ }^{13}$ Screening Report: Turkey, Chapter 11, 7 September 2006, http://ec.europa.eu/enlargement/pdf/turkey/screening_reports/screening_report_11_tr_internet_en. pdf, (02 February 2012); IPA Rural Development (IPARD) Programme for Turkey, MEMO/07/609, Brussels, 20 December 2007

${ }^{14}$ Flam, Herry, Turkey and the EU: Politics and Economics of Accession, CESIF Working Paper No. 893, March 2003, p.22; Olhan, Emine, 'The impact of the Reforms: Impoverished Turkish Agriculture', Agricultural Journal (2): 41-47, 2006, p.42.

${ }^{15}$ Beef and dairy, cereals, oilseeds and some industrial crops were protected at the expense of the more efficient fruit and vegetable sectors.
} 
heavy burdens on the budget and resulted in negative effects to the whole economy, either through payments from the state budget or implicit transfers from consumers. ${ }^{16}$

While the clear failure of the previous policies necessitated undertaking a more radical step, the 2000 agricultural reforms of Turkey were the result of a variety of internal and external factors. ${ }^{17}$ Internally, decreasing the burden of agriculture on the economy after the 1997 and 1999 economic crises was one important stimulus for reforms. On the other hand, internationally binding and non-binding pressures played an important role in the reform initiatives. These are the Uruguay Round agreement on agricultural trade, the accession negotiations with the EU which put 'adjusting to the CAP' on political agenda, the 1999 agreement with the IMF reforming agricultural policy, and the agreement with the World Bank as an important financial supporter for the Agricultural Reform Implementation Project (ARIP).

The major objective of the 2001-2008 ARIP was a move towards a market oriented agriculture policy by the abolition of administered prices and of input and credit subsidies, a restructuring of agricultural state-owned enterprises and agricultural sales cooperatives, the introduction of the Direct Income Support scheme (DIS), and gradual reduction of tariffs and the restructuring of the agricultural production. Under the reform program, output price supports, input subsidies and grants in various forms were to be phased out and replaced by direct payments to farmers based on land holding (decoupled from type or quantity of production).

ARIP in the 2000s ignited a public debate on the possible consequences of these reforms for the agriculture and rural population. Some scholars argued that '.... [with the agricultural reforms] the desired results were not gotten and the agriculture sector experienced a worse process. ${ }^{18}$ One widely-heard contra-reform argument was that they were externally imposed on Turkey by foreign economic powers and therefore serve their own interests together with measured negative impacts on the incomes of farmers and labours, on the productivity and trade capacity of the sector, and on the

\footnotetext{
${ }^{16}$ Turkey in the European Union: Consequences for Agriculture, Food, Rural Areas and Structural Policy, Final Report, 1 December 2004, Agricultural Economics and Rural Policy Group (AEP) \& Agricultural Economics and Research Institute (LEI), Report Commissioned by the Dutch Ministry of Agriculture, Nature and Food Quality, pp.107,111.

${ }^{17}$ See Zülküf Aydın. He claims that liberalization policies in the agriculture already had begun in the 80s under the pressure from international institutions (such as IMF, World Bank and WTO) and transnational agribusiness firms, while the developmentalist policies between 1950-1980 which were supported and encouraged especially by the WTO ensured the capitalization, commercialization and commoditization of agriculture served again international financial interests by Turkey's integration into the capitalist world economy. (pp.149-157) Neo-Liberal Transformation of Turkish Agriculture, Journal of Agrarian Change, Vol. 10 No. 2, April 2010, pp. $149-187$

${ }^{18}$ Avrupa Birliği'ne Yönelik Düzenlemeler Çerçevesinde Türk Tarım Politikaları ve Sektörün Geleceği Üzerine Etkisi, Neslihan Yalçınkaya, M. Hakan Yalçınkaya, Coşkun Cilbant, Yönetim ve Ekonomi, 2006, 13/2, p.97
} 
prices of the agricultural products. ${ }^{19}$. The reforms not being tailor-made to the countryspecific problems in the agricultural sector and not taking into account regional and local differences have increased poverty in rural and agricultural areas, while leaving old problems unsolved such as great income inequality in the sector. ${ }^{20}$ Some others maintained that DIS is implemented in developed countries where there is high productivity and excess agricultural product in order to increase producer incomes without causing a rise in production. In Turkey DIS system cannot improve the ill-balanced agricultural structure and resolve existing problems in agriculture. ${ }^{21}$

On the other hand, the reforms have been evaluated more positively in some circles and by some authors. These positive approaches to the reforms are mainly based on the premise that the reforms prepare the sector for competitive global trade by liberalization and privatization, and Turkey for EU membership by facilitating adaptation to the CAP. At TUSIAD report, Akder defends DIS for Turkey should avoid the support policies which may increase the agricultural product prices which are already in rise in the world due to oil prices and which are already very high in Turkey due to production costs. Against the argument that DIS is a tool for developed countries with production surplus in order to decrease production, he holds that the objective of DIS is not to encourage for non-production but to support farmers whatever they produce. Expected result is that farmers discontinue with excess products and produce products which may more easily be produced according to natural conditions of the farm and be sold according to market conditions. ${ }^{22}$

However, even the reform advocates criticized the way that the reforms were applied and the inconsistencies between the implementation and the initial plans. Reform process could not pursue its original reasons, aims and objectives since it lacked

19 Please see A. Halis Akder, Türkiye Tarım Politikası'nda Destekleme Reformu, ASOMEDYA, Ankara Sanayi Odası,. Aralık 2003; Mine Eroğlu, AB Sürecinde Türkiye Tarımı, 31/07/2005; Buğday Dergisi, http://www.bugday.org/article.php?ID=816, (02 February 2012); Prof. Dr. Oguz OYAN, 2000 ve 2001 Programlarinda Ulusal Tarim Politikalarının Tasfiyesi, Mülkiye, XXV/ 228, 2001, pp. 33-34. For a very good discussion of this argument, see Zülküf Aydin, supra note 16

${ }^{20}$ See especially Aerni, P., Editorial: Agriculture in Turkey - Structural Change, Sustainability and EU- Compatibility, Int. J. Agricultural Resources, Governance and Ecology, Vol. 6, Nos. 4/5, 2007, pp.429-439. Emine Olhan, The Impact of the Reforms: Impoverished Turkish Agriculture, Agricultural Journal, 1 (2): 41-47, 2006.

${ }^{21}$ Olhan, op.cit., p.43

${ }^{22}$ Türkiye'de Tarım ve Gıda: Gelişmeler, Politikalar ve Öneriler, TUSIAD raporu, 2008, pp.31, 33-34, http://www.tusiad.org/bilgi-merkezi/raporlar/turkiyede-tarim-ve-gida--gelismeleler-politikalar-ve-oneriler/ (02 February 2012). Contrary to Akder, a Report Commissioned by the Dutch Ministry of Agriculture (see supra note 15) holds that DIS can only be a political choice for new members since from an economic perspective, supporting the agricultural sector by means of direct income support is not very productive. It keeps labour in agriculture, and it hinders restructuring and farm consolidation because the payment is capitalised into the value of land. For the NMS, however, there was a political decision to introduce the CAP direct income payments, because otherwise there would be a difference in the way farm policy works across EU member states. 
necessary determination and public support. The project could not keep its scope and certainty as announced in the beginning and has been modified several times. There was not enough public consent because sector representatives, lobbies and voluntary associations have not been persuaded for its success. On the contrary, they were in strong opposition to the reforms. ${ }^{23}$

ARIP was already amended in 2005 and extended to the end of 2008. The 20062010 Agricultural Strategy Paper which set the objectives and priorities for Turkish Agriculture $^{24}$, was at the same time a move form decoupled direct support back to more coupled direct support and price support. By the 2006 Agricultural Law, support on the basis of production has been accepted as the main policy instrument. As a result, starting from 2005, the weight of DIS payments in total budgetary support to agriculture has decreased. In 2009, the DIS payments were completely abolished by the government. Since 2009, coupled direct support again became the main type of support to Turkey's agricultural sector. Diesel and fertiliser payments based on the land area with rates varying by the product groups constitute $87 \%$ of the total payments in $2009 .^{25}$

\section{Transformation of the Common Agricultural Policy}

A comparison of EU and Turkey regarding agricultural reform illustrate that Turkish experience in the ARIP project and in the abandoned DIS practice was too radical, sharp and hasty. Although the EU has a much more developed, wealthy and strong agricultural sector, EU reform process has been much more gradual. For decades, the EU's CAP which aimed at encouraging better productivity in the food chain, ensuring fair standard of living to the agricultural community, market stabilization and ensuring the availability of food supplies to EU consumers at reasonable price was based on the price and product supports and high custom tariffs in external borders. Overproduction and increasing costs led to a fundamental reform process of the CAP ${ }^{26}$ which started in 1992 and was later deepened and extended in 1999 with Agenda 2000. Tariffs and intervention prices have been reduced by the MacSharry reform of 1992 and farmers began to receive direct payments for a few key agricultural sectors as compensation for the reduction of intervention prices. Compensation payments were necessary to make the policy reforms politically acceptable and to cushion their shortterm impact on incomes.

The next reform of CAP took place in 1999, with the "Agenda 2000" initiative. This reform was designed to prepare the European Union for the eastward expansion which eventually took place in 2004 and 2007. The major element of this reform was

\footnotetext{
${ }^{23}$ TUSIAD Report (2008), op.cit., p.36

${ }^{24}$ The objective was moving forward the agricultural policy to secure and develop sustainable agricultural production, to ensure product quality, food security and safety, to increase competitiveness of agricultural holdings, to improve markets and marketing, to provide rural development, and to encourage establishment of producers' organizations.

${ }^{25}$ OECD Report, op.cit., p. 47

${ }^{26}$ For a brief history of the CAP, see, http://ec.europa.eu/agriculture/capexplained/change/index en.htm
} 
the splitting of CAP into two pillars. Pillar one focuses on the economic aspects of agriculture, while pillar two focuses on the rural development needed for competitive agriculture. The Agenda 2000 reduced price and export support more, while increasing direct payments. It also introduced "cross-compliance" measures, which meant that farmers had to meet certain environmental standards in order to receive direct payments, limiting ground and water pollution.

Just before the first ten new member states joined, decoupling of direct payments from production were introduced by the 2003 CAP reforms by a new instrument called single farm payment. Approximately $90 \%$ of direct payments granted for crops, meat and milk were converted to area payments decoupled from production. With the reform, "eco-conditionality" strengthened environmental standards and included animal welfare standards which must be met in order for a farmer to receive direct payments. "Modulation" shifted money in the CAP budget from the first pillar to the second pillar, increasing rural development funds for enlargement.

The final reform of the CAP was done under the title of the "Health Check" of 2008. Compared to the previous reforms, this was a modest effort. Modulation to Pillar two was increased, (cutting the funds for large farms $10 \%$ and transferring it for rural development measures) and subsidies were further decoupled from production. Despite the proposals, the Health Check reform failed to set a maximum limit for the Single Farm Payment by the pressure of a strong lobby of large farmers and did not deal with the objections of the NMS to the fact that they continue to receive less funding per hectare in direct subsidies than the older European states. ${ }^{27}$

\section{The Common Agricultural Policy, Rural Development and Turkey}

Historically, rural development has been inextricably linked with agriculture and this is particularly true for the European Union, where the CAP has had a significant impact on rural development. ${ }^{28}$ Rural development refers to development that benefits rural populations; where development is understood as the sustained improvement of the population's standards of living or welfare. In this sense, it is oriented more toward benefiting primarily the poor including the provision of social services to the rural poor and the promotion of standards of living. ${ }^{29}$ Rural development is an issue of particular importance for the majority of the new member states of the EU since they have substantial rural communities, and the agricultural sector makes a large contribution to their national economies. However, in many cases, farms are small and uneconomic and

${ }^{27}$ Douglas K. Knight, Romania and the Common Agricultural Policy, Eco Ruralis, Report, October 2010, www.ecoruralis.ro/storage/files/Documente/ReportCAP.pdf , (2 February 2012), p. 19 .

${ }^{28}$ European Commission, EUR 21331- Rural Development: the Impact of EU Research (1998-2004) - Workshop Report, Luxembourg: Office for Official Publications of the European Communities, 2004, p.5

${ }^{29}$ Gustavo Anríquez and Kostas Stamoulis, Rural Development and Poverty Reduction: Is Agriculture Still the Key?, Agricultural Development Economics Division, the Food and Agriculture Organization of the United Nations, ESA Working Paper No. 07-02, June 2007, www.fao.org/es/esa, (06 July 2012), pp. 2-3 
have suffered from, or continue to suffer from, under-investment and a lack of modern technology. ${ }^{30}$

The socio-economical problems that Turkey may suffer especially in as regards to rural areas during its future adaptation to the CAP may be projected by studying the new member states' problems in a similar transition from protectionist to more liberal policies. Furthermore, the instruments developed by the EU to fight against the negative impacts of the CAP over the rural populations and areas are particularly important for Turkey in order to solve the problems posed by its underdeveloped rural regions since it has become already a beneficiary of these policies as an official candidate.

\section{Implementation of the CAP in the New Member States: Lessons for Turkey}

The new member states and the official candidates to the EU have to adapt in a very short time to the CAP which have evolved (been liberalised) in the decades. Despite to that, the focus has been more on the effects of membership on the EU financially instead of the burden over national economies and agricultural sector and rural population. For example, to date, many projections about the cost of Turkey's membership to the EU and its possible share from the CAP budget have been made. ${ }^{31}$ Most of the studies conclude that Turkish Agriculture will not put a big burden on EU budget. On the contrary, a significant support to agriculture may not be expected while prices and producer welfare decrease. Additionally, full financial support to the agriculture may not be expected in a short-period. Turkey will benefit fully from the EU's budgetary support schemes only some time after 2020. ${ }^{32}$ Aydin underlines this uneven relationship by pointing out that 'the EU's level of modernity has been achieved through huge subsidies over the years and subsidies are still being continued. To force Turkish agriculture to achieve the same level of efficiency without the necessary funds is simply unfeasible. ${ }^{33}$

On the top of these, it is a well-known fact that the CAP is modified before each enlargement and so that existing member-states do not have to make excessive sacrifices for the new-comer while the burden for adopting the CAP is mostly paid by

\footnotetext{
${ }^{30}$ Supranote 28, p. 7

${ }^{31}$ See Harald Grethe, The CAP for Turkey? Potential Market Effects and Budgetary Implications, EuroChoices 4(2), 2005, 20-25; Erol H. Cakmak, Structural Change and Market Opening in Turkish Agriculture, EU-Turkey Working Paper No. 10/September 2004, Centre for European Policy Studies; Daniel Gros, Economic Aspects of Turkey's Quest for EU Membership, CEPS Policy Brief, No. 69/April 2005; Turkey and the EU Budget: Prospects and Issues, Kemal Derviş, Daniel Gros, Faik Öztrak and Yusuf Isık in cooperation with Firat Bayar, CEPS, EU-Turkey Working Papers, No. 6/August 2004; Harald Grethe1, Turkey's Accession to the EU: What Will the Common Agricultural Policy Cost?, Institute of Agricultural Economics and Social Sciences, Humboldt-University of Berlin, Nr. 70/2004; Herry Flam, Turkey And The EU: Politics And Economics of Accession, Cesifo Working Paper No. 893, Category 1: Public Finance, March 2003.

${ }^{32}$ Daniel Gros (2005), op.cit., p.2

${ }^{33}$ Zülküf Aydın, op.cit., p.159
} 
the new member. ${ }^{34}$ For example, in the last enlargement, the EU presented the Central and Eastern European Countries with "tough conditions" for their incorporation in this sector, i.e. opening up their markets but not given the full extent of support and access until the end of long transition periods. ${ }^{35}$ A similar pattern will most probably be applied to Turkey as well. In 2004, the European Commission proposed for Turkey phasing in the direct income support gradually although it is necessary to compensate the farmers in Turkey for price decreases after accession. While the slow integration into CAP and lower production costs and prices experienced in the NMS were justifications for phasing $\mathrm{in}^{36}$, budget restrictions are used as the main argument for limiting direct income support for Turkey. ${ }^{37}$

Concerning the application of DIS which is the core of the CAP's first pillar right now, there are many difficulties experienced by the New Member States. Firstly, millions of small farms most of which are either subsistence farms or semi-subsistence farms joined to the EU agriculture by the last enlargements. While they commonly populate the most fragile and disadvantaged rural areas, their integration with markets and their competitiveness are very problematical. ${ }^{38}$

Davidova underlines that:

Although not excluded from direct aid payments under Pillar 1, due to their small size SFs and SSFs either receive very little, or nothing at all if they are below the minimum area threshold. For example, in Romania around 3 million household farms

\footnotetext{
${ }^{34}$ Lorena Ruano, The Common Agricultural Policy and the European Union's Enlargement to Eastern and Central Europe, Robert Schuman Centre for Advanced Studies, RSCno. 2003/3; Susan Senior Nello, Food and Agriculture in an Enlarged EU, Robert Schuman Centre for Advanced Studies, RSC no. 2002/58.

${ }^{35}$ Ruano (2003), p.1. The general pattern followed by the EU concerning CAP in the enlargements may be summarized as follows: First, enlargement is linked to a reform of the main regimes that will cause trouble, in order to curb future expenditure. Second, given that these reforms have again been insufficient to cope with the consequences of enlargement, the EU's proposed terms of entry consist of long transition periods for the full adoption of the CAP by the new members.

${ }^{36}$ The Eastern European states have certain conditions stipulated to them when they became members of the EU, and one of them was that direct subsidies in the NMS started at only $25 \%$ of the level of the EU-15, rising by 5\% per year until 2010, and then $10 \%$ each year afterward until 2016, when they reach the same level. Douglas K. Knight, op.cit, p.24. With the last CAP reform proposal, it will probably be postponed again to an uncertain date.

37 Turkey in the European Union, op.cit., pp.191-192 The fact that farmers in the NMS experienced lower prices before accession and that there was no reason to compensate them for price decreases, was used only as a justification for phasing in the direct income support gradually. This justification does not apply for Turkey. Nevertheless, phasing in has been proposed by the European Commission.

${ }^{38}$ In seven NMS, most farms produce mainly for self-consumption. These are Slovakia, where in $2007,93 \%$ of the farms produced mainly for self-consumption, Hungary (83\%), Romania (81\%), Latvia (72\%), Bulgaria (70\%) and Slovenia (61\%). Sophia Davidova, Semi-subsistence farming in Europe: Concepts and key issues, European Network for Rural Development, 2010, p.7
} 
are not eligible for the SAPS $^{39}$ (single Area Payments) as they do not fulfill the eligibility criteria. Even when SFs and SSFs do receive some Pillar 1 support, payment distribution is naturally skewed towards larger farms. SAPS beneficiaries represent a relatively small segment of the existing farm holdings in Bulgaria and Slovakia ${ }^{40}$.

This is partly because of the way the CAP is structured and partly a result of implementation (or a lack of implementation) ${ }^{41}$. Many scholars argue that the CAP was specifically designed according to medium sized family farm model of Western Europe. The family farms in the EU15 are the farms with families living and working on them, keeping farmland under cultivation. As small economic units, they are capable of internal trade and export. On the other hand, the average size of the family farm in the new member states is much smaller than the Western European idea of a "family farm". Additionally many eastern European family farms have always been, and continue to be built around self consumption and maybe selling locally. ${ }^{42}$ A current study concludes that the current CAP as a uniform system 'does not fully fit the conditions of the new member countries, especially in their poorest sections. Although the current system allows for certain areas to be treated specially, it is not suitable for providing real assistance to the millions of small farms in the NMS, let alone for tackling rural poverty. ${ }^{43}$

The 'hidden biases' which exist against subsistence and semi-subsistence farms in the CAP provides almost nothing for these farms ${ }^{44}$ This aggravates the rural poverty since 'those that lack a 'fair standard of living' in the rural areas of New Member States are characterized by being either landless or restricted to small plots and they benefit least from the introduction of direct payments, typically being ineligible for the receipt of such funds. The main gainers will be large, corporate farms. ${ }^{45}$ This unfair situation is worsened by the above-mentioned fact that Eastern European farmers receive far less in

\footnotetext{
${ }^{39}$ Recognizing the difficulties of administering the CAP, acceding countries were offered the option to implement a simplified system of direct payments, known as the Single Area Payment Scheme (SAPS) Under the SAPS, farmers in the NMS receive a flat-rate, per-hectare payment irrespective of what is produced as long as their land is maintained in good agricultural condition. C. Hubbard and L. Hubbard, Bulgaria and Romania - Paths to EU Accession and the Agricultural Sector, Centre for Rural Economy Discussion Paper Series, DP 17, 2008, http://www.ncl.ac.uk/cre/publish/discussionpapers, (2 February 2012), p.17

${ }^{40}$ Davidova, op.cit., p.28.

${ }^{41}$ Most of the NMS have chosen 1 hectare as the minimum eligible size for a direct payment. Below 1 hectare, payments were likely to be less than 50 Euro per farmer per year and the administrative burden was deemed too great, as the administrative costs of paying subsidies on a smaller amount of land would outweigh the benefits incurred from the payments. C. Hubbard and L. Hubbard, op.cit., p.17

${ }^{42}$ Douglas K. Knight, op.cit., p.8

${ }^{43}$ Structural Change in Agriculture and Rural Livelihoods: Policy Implications for the New Member States of the European Union, Edited by Judith Möllers, Gertrud Buchenrieder, and Csaba Csaki, Leibniz Institute of Agricultural Development in Central and Eastern Europe (IAMO), Volume 61, 2011, p.220, www.iamo.de/dok/sr_vol61.pdf, (2 February 2012)

${ }^{44}$ Ibid., p. 212

${ }^{45}$ C. Hubbard and L. Hubbard, op.cit., p. 17
} 
subsidies when compared to their Western European counterparts - criticized by some scholars as an unjust treatment to Eastern European farmers who, despite lower production costs, have infrastructure and bureaucratic problems to deal with which their Western European counterparts do not. ${ }^{46}$

\section{Agricultural Policies and Rural Poverty: Turkey and the EU}

Most of the above mentioned effects of the CAP over the new member states in terms of rural development and poverty may be expected to occur in Turkey as well in the case of membership. In fact, they have already been observed for the last decades with an aggravated impact of temporary DIS experiment in Turkish Agricultural Policy. ${ }^{47}$ In a similar way to the new member states, there is a dual structure in Turkish agriculture: large farmers producing for markets and even for export and small farmers based on semi-subsistence farming produce for household consumption. ${ }^{48}$ These small farms are, nonetheless, of crucial importance providing income security, and represent a source of livelihood for the majority of Turkey's rural population. And OECD report adds, they are sufficiently productive to have made Turkey a significant agricultural exporter and a world leader in certain agricultural products. ${ }^{49}$

Yet, subsistence farming is not a phenomenon specific to Turkey, neither to the new member-states. Subsistence farms exist all over the EU (45\% of the EU-27 holdings) and problems of rural development and rural poverty are still not solved in many EU member-states:

The diffusion of very small or even semi-subsistence farms is a matter of serious concern because in most Eastern and Mediterranean countries (Bulgaria, Lithuania, Romania, Greece, Italy, Portugal) less than $30 \%$ of farmers have other gainful activities which can top up the income received from agricultural activities. Diversified sources of income may indeed reduce the risk of poverty among farmers. Therefore small farmers appear to be a specific group at risk of poverty and social exclusion in rural areas. ${ }^{50}$

A number of dilemmas exist at the intersection of the areas of agricultural policies and rural development. The agricultural incomes (earned or paid by the authorities) of most small farms fail to provide them with an acceptable level of living. Even if they can accomplish to produce more, the majority of them have hardly any connection with national or regional markets. Two other options for increasing income-diversification of income sources at place or migration- may not work for underdeveloped rural areas

\footnotetext{
${ }^{46}$ Douglas K. Knight, op.cit., p.23

${ }^{47}$ For a very interesting research on the transformation of farms and farmers in Turkey with liberalization of Turkish agriculture, see Çağlar Keyder and Zafer Yenal, Agrarian Change under Globalization: Markets and Insecurity in Turkish Agriculture, Journal of Agrarian Change, Vol. 11 No. 1, January 2011, pp. 60-86.

${ }^{48}$ Rural Development Policies (2007), op.cit., p.5

${ }^{49}$ OECD (2011), op.cit., p. 8

50 European Commission: Directorate-General for Employment, Social Affairs and Equal Opportunities Unit E2, Poverty and Social Exclusion In Rural Areas Executive Summary, Manuscript completed in September 2008, p.19
} 
because of two vicious circles: 'labor market circle' and 'education circle"51. First of all, the number of jobs outside agriculture is also limited in rural areas, which force many qualified people to migrate and thus worsen the quality of the local labor force; which in return works as a disincentive for investment in the area; the consequence is a further deterioration of labor market situation. Secondly, the low educational levels of most of the rural population cause a low employment rate even at the areas with more job opportunities and turns migration to a problem, rather than solution ${ }^{52}$. This consequently, may increase the poverty rate, which in turn negatively affects the chance of receiving high quality education.

In agricultural sector, employment percentage and economic development seem to be in inverse proportion. The shrinking agricultural sector due to modernization and technological reforms results in increasing unemployment due to inflexibility of the agricultural labour force which lacks necessary education and training for alternative employment opportunities. For example, in Turkey the share of the agricultural sector in total employment, which was 50 percent in 1980, went down to 24 percent in 2010. However, the fact that the work force that left the agricultural sector could not be employed adequately in industry and services sectors led to a decrease in employment rates in the mentioned period. ${ }^{53}$ As a result, migration from rural to urban areas has increased significantly.

A report prepared by ENEPRI emphasizes that;

'Turkey and Romania stand out with a very large share of the labour force in agriculture, mainly subsistence agricultural activities, characterized by very low productivity. Given the very low productivity levels of agriculture and the fact that a substantial part of this employment is in fact related to subsistence agriculture rather than production for the market, the process of labour shifting between sectors is likely to take place in these countries over the coming years and decades both creating problems and opening up opportunities, ${ }^{54}$

On the other hand, subsistence agriculture with low productivity does not pose an immediate threat in terms of hunger or malnutrition. On the contrary, 'Turkey's agricultural support policies as well as the local safety nets ensure that most people enjoy minimal standards of living even if they are very poor. ${ }^{55}$ However, as underlined

\footnotetext{
${ }^{51}$ Ibid., p. 11

${ }^{52}$ For Turkey, the illiteracy in the agricultural employment is \%18, significantly higher than the rest of the economy. Major contributor to this rate is employed females with 60 percent share in agricultural employment where 28.5 percent are illiterate. In rural areas, additionally, teaching staff and educational material infrastructures are insufficient which makes the shift to other sectors impossible. Erol H. Cakmak, op.cit., p.7

${ }^{53}$ Harun Ucak, Monitoring Agriculture of Turkey before Accession Process for Membership, Journal of Central European Agriculture, Vol.7, no.3, 2006, p.545.

${ }^{54}$ The Social Dimension in Selected Candidate Countries in the Balkans-Bulgaria, Romania, Croatia and Turkey: Synthesis Report, ENEPRI Research Report No. 37, BALKANDIDE, December 2007, pp.6-7.

${ }^{55}$ P. Aerni, op.cit., p. 430
} 
at the report prepared by IAMO, there is a risk that policies strongly in favor of commercialization through incentives encouraging structural change might undermine the safety net provided by subsistence production. ${ }^{56}$

The countries of frequent economic crises such as Turkey may go through the crises with low social costs thanks to high agricultural employment ${ }^{57}$ and safety-net function of subsistence agriculture. However, the other side of the coin discloses the rural poverty hidden behind the survival strategies. First of all, low unemployment rates in rural areas are partly due to high rates of unpaid family labour (particularly among females) and partly to the way employment is measured (part-time work of even a few hours per week included). In a similar way, a very large share of the employment in the EU is not occupied full-time in agriculture (around 33\% of the family and regular workers in the EU-27 are working less than half time in agriculture and only $37 \%$ of them have full time jobs). In 2008, the average agricultural income in the EU-15 (the countries in the European Union before 2004) was equal to $58 \%$ of the average wage in the total economy, however in the EU-12 it still stands at about 30\% of average wages ${ }^{58}$ a very close percentage to Turkey. Additionally, most agricultural workers have no social security coverage. ${ }^{59}$

As simply pictured above, many problems concerning rural development and rural poverty are still unsolved in the European Union as well as in Turkey. That's why rural development has to be an internal component of an agricultural policy. Concerning Turkey, it shows us that any agricultural reform process should be carefully designed since an abrupt decline in agricultural labour force may lead to serious problems rather than speed up the development efforts ${ }^{60}$ under these domestic and global circumstances. A new domestic policy approach to rural development that is focused on facilitating change in the countryside through more investment in human capital and entrepreneurial infrastructure may generate off-farm employment and improve agricultural competitiveness. ${ }^{61}$

\section{The EU's Rural Development Policies and Turkey}

If small farms are to survive and rural poverty to decline, rural population need to decrease their reliance on farm incomes and combine their farming with diversification and/or off-farm activity. This, however, can only be achieved with rural and regional development that can improve the attractiveness of rural areas to non-farm industries and increase job opportunities. In this context, the CAP has two pillars since 1999: the 1st pillar concentrates on providing a basic income support to farmers, who are free to produce in response to market demand, while the 2nd pillar supports agriculture as a

\footnotetext{
${ }^{56}$ Structural Change in Agriculture, op.cit., p.ix

${ }^{57}$ 21.Yuzyilda Türkiye Tarım1, Agricultural Report of TUSIAD, 2005, p. 54

${ }^{58}$ Situation and Prospects, op.cit., p. 23, 41

${ }_{59}$ Turkey in the European Union, op.cit., pp.142-144; Prime Ministry, Institution of Turkey

Statistics, No: 150, 15 September, 2008 10:00, Haber bulteni.

${ }^{60}$ Çakmak, op.cit. pp.7-8

${ }^{61}$ Aerni, op.cit., pp. 432-433
} 
provider of public goods in its environmental and rural functions, and rural areas in their development and addresses the multiple roles of farming in society, in particular challenges faced in its wider context.

In the EU, rural development policies were introduced for the first time, by the 1992 MacSharry reforms by taking measures to support rural economic diversification and environmental protection. The Agenda 2000 package carried the MacSharry reforms a stage further and defined rural development as the CAP's "Second Pillar" (price and income support being the first). Village and agriculture modernization, development of alternative economic branches, protection of the environment and of the rural landscape were among the goals of the second pillar which aims to help farmers to diversify, to improve their product marketing and to otherwise restructure their businesses.

The Fischler reform of 2003, originally meant as a Mid Term Review (MTR) of Agenda 2000, linked "single farm payments" to respect for environmental, food safety and animal welfare standards through the "cross compliance. Secondly it shifted funds more from Pillar I to Pillar II (rural development) by reducing subsidies awarded to large farms. Following the Fischler reform, the Agricultural Council adopted in 2005 a fundamental reform of rural development policy for the period 2007 to 2013. The rural development policy for the 2007-2013 period focuses on three core objectives, namely the improvement of the competitiveness of the farming and forestry sectors, the improvement of the environment and the countryside through support for land management, and the improvement of the quality of life in rural areas and the promotion of diversification of economic activities.

The European Union's rural development policies have the potential to become a chance for Turkey, as rural development policy is to be considered an integrative approach which encompasses the role of agriculture; the environment; the quality of products; human resources; employment; life conditions etc., both individually and as a whole. ${ }^{62} . € 131$ million of a financial aid of $€ 654$ million in total by the EU has been allocated to the Rural Development Program for the Republic of Turkey for 2010. The main policy objectives of the Instrument for Pre-Accession Assistance for Rural Development (IPARD) ${ }^{63}$ program are to contribute to the modernization of the agricultural sector and to contribute to the sustainable development of rural areas while facilitating Turkey's move towards a gradual alignment with the acquis concerning the CAP. Moreover, development and diversification of the rural economy, increase of

\footnotetext{
${ }^{62}$ Rural Development Policies, op.cit., pp.4-5. At the same paper it is stated that there is a lack of information and experience concerning the way to implement these "new" policies. And finally, there is a lack of communication with the public about possible changes and developments in Turkey. (p.2)

${ }^{63}$ The Instrument for Pre-Accession Assistance (IPA) established by the EU as a new framework for assistance to candidate countries and potential candidate countries in 2006.
} 
quality of life and attractiveness of the rural areas, counteracting rural out-migration are among the strategic objectives. ${ }^{64}$

The IPARD funds are to be implemented through a single multi-annual "Rural Development Programme" covering the period 2007-2013. In January 2006, Turkey adopted a National Rural Development Strategy (NRDS) providing the first rural development strategy plan for the country. The NRDS sets a comprehensive policy framework for rural development policies in Turkey. The IPARD programme is an important part of this overall strategy. The NRDS identifies the main aim in rural development as "to improve and ensure the sustainability of living and job conditions of the rural community in its territory, in harmony with urban areas, based on the utilization of local resources and potential, the protection of the rural environment and cultural assets." 65 The NRDS states that "the basic resource in strengthening rural economy is the local assets possessed by the rural areas." Among basic assets of the rural areas can be listed the diversity of products, the purer environment, the diversity of natural resources, the richer landscape, and the unique historical and cultural heritage. The assets have to be converted into innovative local opportunities and promoted to create a diversified rural income and additional employment opportunities. ${ }^{66}$

In this context four strategic objectives are; economic development and increasing job opportunities, strengthening human resources, organization level and local development capacity, improving rural physical infrastructure services and life quality, improving rural physical infrastructure services and life quality. In over all some priorities of rural development plan are increasing the competitiveness of the sector, diversification of the rural economy, combating against poverty and improving employability of disadvantaged groups, strengthening education and health services, improvement of environmental friendly agricultural practices. ${ }^{67}$

In 2011, a very detailed Rural Development plan has been prepared by the Ministry of Agriculture for the period of 2010-2013. In accordance with the objectives and priorities set by national rural development strategy, the measures, the activities, the sub-activities and the responsible institutions are defined elaborately at the plan. Of key importance for IPARD is that it is based on a fully decentralised implementation. The EU requires the establishment of robust institutions, run by well trained staff, operating according to well designed and rigorously tested procedures. After three years of intensive preparation, Turkey has been granted in 2011 by the Commission's Decision Conferral of Management of EU funds for the IPARD. This has paved the way for Turkey to operate EU financed investments in agricultural holdings as well as in

${ }^{64}$ MEMO/07/609, IPA Rural Development (IPARD) Programme for Turkey, Brussels, 20 December 2007, p.2

65 Republic of Turkey Prime Ministry, State Planning Organization, National Rural Development Strategy, Ankara, 2006, p.12

${ }^{66}$ Ibid. pp. 14

${ }^{67}$ Ibid., pp. 14-24 
processing and rural development projects. This also marks a key element for the accession negotiations in this chapter. ${ }^{68}$

\section{A New Turn in the CAP and Future Perspectives for Rural Development}

A new reform process in the EU started with the earlier Communication of the Commission in November 2010 and entered a new phase in October 2011 with the publication of the Commission's legislative proposals for the new CAP regulations after 2013. These proposals, initiate the legislative procedure to agree the new regulations which may take up to 18 months to complete.$^{69}$ Reform process in the CAP shows us a paradigm change in the agricultural policy of the EU. A shift from productivist agenda which focuses on agricultural competitiveness and productivity, to a public good agenda which places more focus on the role of farming for the provision of public goods and therefore advocates that policy should support integrated rural development. ${ }^{70}$ The priorities of the CAP moves back from a market-oriented competitive model to a balanced attitude by focusing on some challenges underlined by the European Commission ${ }^{71}$ such as long-term food-security for European citizens and the world, sustainable management of natural resources, biodiversity and climate change, and rural development problems including local employment, poverty and migration. Another indication of paradigm shift is that farming's role as supplier of environmental goods, as the basis of local traditions and of the social identity and as protector of food diversity constitutes one of the fundamentals of the latest CAP reform proposal. This is clearly expressed with the following argument for continuation of public support to less competitive areas: marginalization and land abandonment at these areas would result in 'increased environmental pressures and the deterioration of valuable habitats with serious economic and social consequences including an irreversible deterioration of the European agricultural production capacity, ${ }^{72}$ A new understanding of rural communities and small farms as the providers of public goods such as food security and diversity, environmental protection and cultural assets, albeit uncompetitive in the market, is brought as justifications for a strong public policy for supporting them because "the goods provided by the agricultural sector cannot be adequately remunerated and regulated through the normal functioning of markets. ${ }^{73}$

\footnotetext{
68 Turkey 2011 Progress Report, European Commission, SEC(2011) 1201 final, Brussels, 12.10.2011, p.67; Delegation of the European Union to Turkey, Press Release, Green Light for EU Support to Rural Development Institutions in Turkey, October 2011, Ankara

${ }^{69}$ Alan Mathews, Post-2013 EU Common Agricultural Policy, Trade and Development: A Review of Legislative Proposals ICTSD Programme on Agricultural Trade and Sustainable Development; Issue Paper No.39; International Centre for Trade and Sustainable Development, Geneva, Switzerland, 2011, p.viii.

${ }^{70}$ Davidova, op.cit., p.6

${ }^{71}$ European Commission, The CAP towards 2020: Meeting the food, natural resources and territorial challenges of the future, $\operatorname{COM}(2010) 672 / 5$, Brussels.

${ }^{72}$ Ibid., p. 4

${ }^{73}$ Ibid.
} 
Although competitiveness and market-orientation is preserved by keeping the direct income payments as the main instrument of the first pillar, its justification is no more a temporary compensation for the farmers at the transition from protectionist policies to liberalization of European agriculture but to contribute to farm incomes by taking into account that price and income volatility and natural risks are more marked than in most other sectors and farmers' incomes and profitability levels are on average below those in the rest of the economy. Additionally, DIS' original motivation which is to encourage the uncompetitive farms (especially small ones with subsistence or semisubsistence agriculture) to leave the market is set aside by a new objective: to compensate for production difficulties in areas with specific natural constraints because such regions are at increased risk of land abandonment. This is more clearly expressed at the objectives of the Pillar of Rural Development, though with a different valuepriority: to allow for structural diversity in the farming systems, improve the conditions for small farms and develop local markets because in Europe, heterogeneous farm structures and production systems contribute to the attractiveness and identity of rural regions. Among the other objectives related to rural development are to support rural employment and maintaining the social fabric of rural areas and to improve the rural economy and promote diversification to enable local actors to unlock their potential and to optimize the use of additional local resources. ${ }^{74}$

Among many factors and challenges which lead the EU to take such a turn at the CAP, the 2004 and 2007 enlargements have a special place. The problems unsolved and created by the CAP at these New Member States in a way seem to force the Union to revise the CAP. For example, the Commission lists among the new challenges 'to make best use of the diversity of EU farm structures and production systems, which has increased following EU enlargement, while maintaining its social, territorial and structuring role. ${ }^{75}$ Additionally, to reorganize the distribution of the funds among the Member states in a more fair and equitable way had become inevitable. At the same document, one of the reasons for reform of the CAP is to make CAP support equitable and balanced between Member States and farmers by reducing disparities between Member States taking into account that a flat rate is not a feasible solution, and better targeted to active farmers.

Unfortunately, after ambitious objectives expressed at the communication of the Commission in 2010 , the legal proposals ${ }^{76}$ presented to European Parliament and the Council created a disappointment for the European politicians and public. They were mainly found so weak and unsatisfactory ${ }^{77}$. They were accused to be "clever packaging

\footnotetext{
${ }^{74}$ Ibid.

${ }^{75}$ Ibid., p.6

${ }^{76}$ See European Commission, Proposal for a Regulation of the European Parliament and of the Council establishing rules for direct payment schemes for farmers under the common agricultural policy, $\operatorname{COM}(2011) 625 / 3$, Brussels. Unfortunately, it is not possible the content of these proposals within the scope of this paper.

See 'Europe's farm reform off to rocky start', Euractiv, 17 October 2011 http://www.euractiv.com/cap/europes-farm-reform-rocky-start-news-508298
} 
masking a continuation of the status quo". The reform could not let go off the outdated "old rural policy paradigm". This paradigm looks at the countryside solely through the lens of agriculture, even though the latter's role in the economy has been steadily decreasing. Most environment-focused NGOs such as WWF, Friends of the Earth, Birdlife and the European Environmental Bureau (EEB) were disappointed by the Commission's proposals. They perceive the Commission's proposals to be business as usual instead of the profound reform needed to answer the urgent sustainability challenges. ${ }^{78}$

\section{Conclusion}

Despite to positive developments at the area of rural development policy, especially in the framework of IPARD, Turkish Agricultural policy is still under criticism because Turkey's new agricultural strategy is moving from decoupled direct support back to more coupled direct support and price support while 'decoupled income support is the main tool to support farming in the EU, counting for most of the agricultural expenditure on direct support'. ${ }^{79}$ Both as an official candidate to the EU and as a signatory to WTO agreements, Turkey is under international pressure ${ }^{80}$ concerning its protectionist approach to the agriculture. However, Turkey faces a difficult choice for future planning of agriculture. On the one hand, socio-economic costs of the reforms compatible with the CAP is too high to bear alone especially for a membership at an indefinite date, on the other hand Turkish agriculture should be in any case prepared to global competition by overcoming the structural problems. Furthermore, the obligations arising from the WTO and from the accession negotiations have to be fulfilled.

From the analysis above, it may be argued that Turkish agricultural and rural problems are not unique, nor more grave or severe than some of the countries that already have become the EU members. On the other hand, neither protectionist policies nor DIS as a liberalizing instrument on their own would help to solve the old and deep structural problems of the agriculture and rural underdevelopment- as can be observed from the above analysis on the CAP reform processes in the EU. ${ }^{81}$ Moreover, liberalized agricultural policies together with direct income support as the main instrument have the potential to deepen and worsen the problems at the rural areas such as rural poverty, unemployment and uneven distribution of welfare, as discussed at the second part of

\footnotetext{
${ }^{78}$ Friends of Europe, The future of farming: background briefing, November 2011; European LEADER Association for Rural Development - AISBL, ELARD reaction to the EC legal proposals for the CAP after 2013, November 2011.

${ }^{79}$ Screening Report, op.cit., p. 15

${ }^{80}$ In the 2011 Progress Report, the European Commission underlines that agricultural support policy differs substantially from the CAP as coupled direct support continues to be the main type of support to Turkey's agricultural sector and there is still no strategy for its alignment. Of course it should be kept in the fact that Chapter 11 - Agriculture and Rural Development was frozen by the EU in 2006, together with other seven chapters

${ }^{81}$ Within this context, the post-2013 CAP reforms by the EU should be watched closely by Turkey despite to flaws and inefficiencies of the concrete measures and instruments proposed in the legal packages.
} 
this article for the new Member States. Additionally, Turkey, in the case of full membership, probably will have to put up with the costs and consequences expected and unexpected to arise from the CAP without sufficient support of the EU.

These circumstances demand Turkey to position its agricultural policy in a comprehensive setting with a more weighted and strategic use of rural development policies. Rather than fall back into counter-productive and politicized vicious circle of protectionism, a tailor-made but coherent agriculture and rural development policy that seeks to attain a delicate balance between liberalization and social policies, may better serve Turkey in coping with the problems such as unemployment, migration, economic inequality, and uneducated labour. In this sense, candidacy process to the EU may be an opportunity if the available funds and support from the EU can be used efficiently and properly. The rural development programs designed for the candidate countries force them to make detailed plans and well-structured reforms while they are flexible enough by giving each country the necessary discretion in decision-making to determine its own priority areas and to reformulate the measures according to its specific problems and conditions. Last but not least, in order to avoid the mistakes of the 2000 agricultural policy reform process, to adopt a gradual approach based on adequate communication with the stake holders and on democratic public debate may create more stable and efficient results for solution of structural and infrastructural problems of Turkey in medium and long terms.

\section{References}

P. Aerni, Editorial: agriculture in Turkey-Structural Change, Sustainability and EU-Compatibility, Int. J. Agricultural Resources, Governance and Ecology, Vol. 6, Nos. 4/5, 2007

A. Halis Akder, Türkiye Tarım Politikası'nda Destekleme Reformu, ASOMEDYA, Ankara Sanayi Odası, Aralık 2003

Zülküf Aydın, Neo-Liberal Transformation of Turkish Agriculture, Journal of Agrarian Change, Vol. 10 No. 2, April 2010

Erol H. Çakmak, Structural Change and Market Opening in Turkish Agriculture, EUTurkey Working Paper No. 10/September 2004, Centre for European Policy Studies

Sophia Davidova, Semi-subsistence farming in Europe: Concepts and key issues, European Network for Rural Development, 2010

Delegation of the European Union to Turkey, Green Light for EU Support to Rural Development Institutions in Turkey, Press Release, October 2011, Ankara

Kemal Derviş, Daniel Gros, Faik Öztrak and Yusuf Işık in cooperation with Fırat Bayar, Turkey and the EU Budget: Prospects and Issues, CEPS, EU-Turkey Working Papers, No. 6/August 2004

Devlet Planlama Teşkilatı, Republic of Turkey Prime Ministry, National Rural Development Strategy, Ankara, 2006 
ENEPRI, The Social Dimension in Selected Candidate Countries in the BalkansBulgaria, Romania, Croatia and Turkey: Synthesis Report, ENEPRI Research Report No. 37, BALKANDIDE Project, December 2007, http://www.enepri.org, (05 February 2012)

Gustavo Anríquez and Kostas Stamoulis, Rural Development and Poverty Reduction: Is Agriculture Still the Key?, Agricultural Development Economics Division, the Food and Agriculture Organization of the United Nations, ESA Working Paper No. 07-02, June 2007, www.fao.org/es/esa, (06 July 2012)

Mine Eroğlu, AB Sürecinde Türkiye Tarımı, 31/07/2005; Buğday Dergisi, http://www.bugday.org/article.php?ID=816, (02 February 2012)

Euractiv, 'Europe's Farm Reform off to Rocky Start', 17 October 2011 http://www.euractiv.com/cap/europes-farm-reform-rocky-start-news-508298, (2 February 2012)

European Commission, Turkey 2011 Progress Report, SEC (2011) 1201 final, Brussels, 12.10.2011

European Commission, Agricultural Economic Briefs, Structural development in EU agriculture, Brief $\mathrm{N}^{\circ} 3$ - September 2011, European Commission: Agriculture and Rural Development, http://ec.europa.eu/agriculture/agrista/economic-briefs/, (19 November 2011).

European Commission, Proposal for a Regulation of the European Parliament and of the Council Establishing Rules for Direct Payment Schemes for Farmers under the Common Agricultural Policy, $\operatorname{COM}(2011)$ 625/3, Brussels.

European Commission, The CAP Towards 2020: Meeting the Food, Natural Resources and Territorial Challenges of the Future, $\operatorname{COM}(2010) 672 / 5$, Brussels.

European Commission, Agriculture and Rural Development, Country Profile http://ec.europa.eu/agriculture/enlargement/countries/turkey/profile_en.pdf, (02 February 2012)

European Commission, Situation and Prospects for EU Agriculture and Rural Areas Directorate-General for Agriculture and Rural Development, December 2010.

European Commission, Directorate-General for Employment, Social Affairs and Equal Opportunities Unit E2, Poverty and Social Exclusion in Rural Areas Executive Summary, Manuscript completed in September 2008

European Commission, EUR 21331-Rural Development: The Impact of EU Research (1998-2004)-Workshop Report, Luxembourg: Office for Official Publications of the European Communities, 2004

European LEADER Association for Rural Development, AISBL, ELARD Reaction to the EC Legal Proposals for the CAP After 2013, November 2011

European Union, IPA Rural Development (IPARD) Programme for Turkey, MEMO/07/609, Press Relaease, Brussels, 20 December 2007, http://europa.eu/rapid/pressReleasesAction.do?reference=MEMO/07/609, $\quad(05$ February 2012) 
European Union, Screening Report: Turkey, Chapter 11, 7 September 2006, http://ec.europa.eu/enlargement/pdf/turkey/screening_reports/screening_report_11 tr_internet_en.pdf, (02 February 2012)

Eurostat News Release, Reference: STAT/11/147 Date: 11/10/2011. http://ec.europa.eu/eurostat, (19 December 2011).

Eurostat, Agriculture and Fishery Statistics, Main Results: 2009-2010, Eurostat Pocketbooks, European Commission, 2011ed. http://ec.europa.eu/eurostat, (17 November 2011).

Eurostat, Agricultural Statistics; Main Results 2008-2009, Eurostat Pocket Books, 2010 Edition, The European Commission.

Herry FLAM, Turkey and the EU: Politics and Economics of Accession, CESIF Working Paper No. 893, March 2003

Friends of Europe, The Future of Farming: Background Briefing, November 2011

Daniel Gros, Economic Aspects of Turkey’s Quest for EU Membership, CEPS Policy Brief, No. 69/April 2005

Grethel Harald, The CAP for Turkey? Potential Market Effects and Budgetary Implications, EuroChoices 4(2), 2005

Grethel Harald, Turkey's Accession to the EU: What Will the Common Agricultural Policy Cost? Institute of Agricultural Economics and Social Sciences, HumboldtUniversity of Berlin, Nr. 70/2004

Heinrich Böll Foundation, Rural Development Policies: A Chance for Turkey during the EU Accession Process?, 2007, pp.4-5 www.boell.be/download_en/Text_Tuerkei.pdf. (11 October 2009)

C. Hubbard and L. Hubbard, Bulgaria and Romania - Paths to EU Accession and the Agricultural Sector, Centre for Rural Economy Discussion Paper Series, DP 17, 2008, http:/www.ncl.ac.uk/cre/publish/discussionpapers, (2 February 2012)

IAMO, Structural Change in Agriculture and Rural Livelihoods: Policy Implications for the New Member States of the European Union, Judith Möllers, Gertrud Buchenrieder, and Csaba Csaki (Eds.), Leibniz Institute of Agricultural Development in Central and Eastern Europe, Volume 61, 2011 www.iamo.de/dok/sr_vol61.pdf, (2 February 2012)

Investment Support and Promotion Agency of Turkey, Republic of Turkey Prime Ministry, Turkish Agriculture Industry Report, July 2010.

Çağlar Keyder and Zafer Yenal, Agrarian Change under Globalization: Markets and Insecurity in Turkish Agriculture, Journal of Agrarian Change, Vol. 11 No. 1, January 2011.

Douglas K. Knight, Romania and the Common Agricultural Policy, Eco Ruralis, Report, October 2010, www.ecoruralis.ro/storage/files/Documente/ReportCAP.pdf, (2 February 2012)

Alan Mathews, Post-2013 EU Common Agricultural Policy, Trade and Development: A Review of Legislative Proposals ICTSD Programme on Agricultural Trade and Sustainable Development; Issue Paper No.39; International Centre for Trade and Sustainable Development, Geneva, Switzerland, 2011 
Susan Senior Nello, Food and Agriculture in an Enlarged EU, Robert Schuman Centre for Advanced Studies, RSC no. 2002/58.

OECD, Evaluation of Agricultural Policy Reforms in Turkey, OECD Publishing., 2011, http://dx.doi.org/10.1787/9789264113220-en, (02 February 2012).

Emine Olhan, The Impact of the Reforms: Impoverished Turkish Agriculture, Agricultural Journal, 1 (2): 41-47, 2006.

Arie Oskam, Alison Burrel, Tugrul Temel, Siemen van Berkum, Natasha Longworth, Irene Molina Vílchez, Turkey in the European Union: Consequences for Agriculture, Food, Rural Areas and Structural Policy, Final Report, 1 December 2004, Agricultural Economics and Rural Policy Group (AEP) \& Agricultural Economics and Research Institute (LEI), Report Commissioned by the Dutch Ministry of Agriculture, Nature and Food Quality http://www.econturk.org/Turkisheconomy/turkey-eu-agriculture.pdf, 05 February 2012

Oguz Oyan, 2000 ve 2001 Programlarinda Ulusal Tarım Politikalarının Tasfiyesi, Mülkiye, XXV/ 228, 2001

Lorena Ruano, The Common Agricultural Policy and the European Union's Enlargement to Eastern and Central Europe, Robert Schuman Centre for Advanced Studies, RSCno. 2003/3

Türkiye İstatistik Kurumu (TÜİK),

www.tuik.gov.tr/PreIstatistikTablo.do?istab_id=53, (19 December 2011).

Türkiye İstatistik Kurumu (TÜİK), No: 150, 15 September, 2008 10:00, Haber Bülteni, http://www.tuik.gov.tr/PreHaberBultenleri.do?id=2049

TUSIAD, 21.Yüzyılda Türkiye Tarımı, Tarım Raporu, 2005.

TUSIAD, Türkiye'de Tarım ve Gıda: Gelişmeler, Politikalar ve Öneriler, TUSIAD Raporu, 2008. http:/www.tusiad.org/bilgi-merkezi/raporlar/turkiyede-tarım-vegıda--gelişmeler--politikalar-ve-öneriler/ (02 February 2012).

Harun Ucak, Monitoring Agriculture of Turkey Before Accession Process for Membership, Journal of Central European Agriculture, Vol.7, no.3, 2006

World Bank, World Development Indicators, Official Website, 2010. http://data.worldbank.org/indicator, (20 December 2011).

Neslihan Yalçınkaya, M. Hakan Yalçınkaya, and Coskun Cilbant, “Avrupa Birliği’ne Yönelik Düzenlemeler Çerçevesinde Türk Tarım Politikaları ve Sektörün Geleceği Üzerine Etkisi”, Yönetim ve Ekonomi, 2006, 13/2. 